\title{
Organic and conventional sweetpotato production in the Southeastern of United States: a comparative analysis
}

\author{
Sochinwechi Nwosisi ${ }^{1}$, Prabodh Illukpitiya ${ }^{1 *}$ (D) Dilip Nandwani ${ }^{1}$, Ismail Tubosun Arebi ${ }^{2}$ and Obinna Nwosisi ${ }^{2}$
}

\begin{abstract}
Background: There has been a piqued interest in alternative agricultural production systems that are environmentally friendly due to concerns on how sustainable it is to grow conventionally. However, in the producer's point of view, economic returns are an important issue in decision-making in adaptation. The purpose of this study is to assess the economic risk of conventional and organic sweetpotato production in the Southeastern US. The primary and secondary data were used for the analysis. We identified risk variables in stochastic profit function and performed Monte Carlo simulation in analyzing profitability and economic risk of conventional and organic production systems.

Results: Findings from the meta-analysis suggest lower sweetpotato yields and higher selling prices, are to be expected in the organic sweetpotato production systems compared with the conventional. A higher probability of having positive net return from organically grown sweetpotato compared to conventional production systems was observed.

Conclusions: Increase in unit cost leads to a decrease in net profit in both conventional and organic production systems. Sweetpotato price has more effect on net return compared to its yield in conventional production systems. The higher selling price, lower yield and lower unit costs provide a higher net profit return for the organic sweetpotato production systems. Unit cost in conventional production was noted to be higher in general, inferring conventional sweetpotato production could potentially experience a higher variability in net farm income. Despite the high production cost, however, farmers are encouraged to go into sweetpotato production as it appears to be profitable. Further studies should be conducted on conventional treatments without synthetic pesticides and fertilizers as these systems perhaps, may display lower external input costs that might make them more profitable similar to organic systems.
\end{abstract}

Keywords: Net return, Organic production, Price premium, Sensitivity analysis, Monte Carlo simulation

\section{Background}

Despite the current pandemic noxious, sweetpotato remains an important vegetable grown in the United States (US) with an income source for growers and a vital food source for consumers [43]. It has been replaced

*Correspondence: pillukpi@tnstate.edu

${ }^{1}$ Department of Agricultural and Environmental Sciences, Tennessee State University, 3500 John A. Merritt Blvd, Nashville, TN 37209, USA

Full list of author information is available at the end of the article with other crops because it produces more food energy per unit area under low-input production situations [44]. Over the last 40 years, sweetpotato production has remained relatively stable despite the doubling in world population [17, 20,31]. Possible reasons include its perception as a 'poor man's food', production costs and flavor of the cooked product [20]. Given that the importance of food supply to alleviate food insecurity specially among rural households $[1,9,25,35]$ and considering the high energy and nutritional value, sweetpotato can be an 
impotent crop to improve household food insecurity [11]. The United States emerged as the world's sixth largest, sweetpotato producing country in 2013, fifth in 2017 and tenth in 2020 with an annual production of 1.1 million metric tons, $\sim 1 \%$ of world's total sweetpotato production $[18,37]$. Southeastern region in US is popular for sweetpotato production and North Carolina is the leading State in sweetpotato production [17, 36, 41, 42].

There has been a piqued interest in alternative agricultural production systems that are environmentally friendly due to concerns on how sustainable it is to grow conventionally $[6,30]$. Organic farming has been recommended as its goals include the production of produce nutritious food with little or no pesticides while bringing more profit, maintaining and sustaining healthy ecosystems, people and environment $[8,22,32]$ for present and future generations. However, it is often argued that organic agriculture yields less than the conventional and would require more land area to produce equal amounts of food, leading to deforestation, and loss in biodiversity thus nullifying the environmental gains of organic farming techniques $[32,38]$. Organic agriculture has grown steadily worldwide over the last few years and the United States is one of the world highest consumer of organic food [36]. For example, the consumer surveys revealed that organic products that have been certified are easily seen in most grocery stores, are purchased by $84 \%$ of American consumers and obtain price premiums of substance in the United States [36]. According to an organic survey and certified organic farm data by the USDA National Agricultural Statistical Service (NASS) in 2015, 229 organic sweetpotato farms were spanning 2831 ha with a total production of 105.2 million $\mathrm{kg}$ of sweetpotatoes worth $\$ 70.8$ million $[40,42]$. The sweetpotato was on record as the fourth highest commodity sales of all organic vegetables grown in the open [43].

Techniques for analyzing the economic impacts of alternative farming practices at the farm level can involve several methods, but at the heart of this is a basic benefit-cost analysis [4]. The common way a producer can use to determine the profitability of his farm business after employing the use of more sustainable farming techniques is by measuring the impact of changes in input/output quantities and fluctuations in prices [4]. Enterprise budgets can be measured alongside other producers' costs or industry averages to see if the individual farm's costs are high or low in comparison and if costs are high, then budgeting will highlight particular areas that need further analysis [5]. Changes in the weather, insect attacks, and diseases, etc., can reduce yields and crop quality, minimal variances in total supply and demand for products can escalate rapidly to notable changes in prices, and variances in regulations can change growers' production techniques and costs [15]. In the same vein, alterations in production methods that can lead to a reduction in production costs without influencing yields can result in increased profits [5]. However, the absence of detailed records can prevent adequate insight into the effect of changing production practices on profit [5].

According to US farm survey data, production risks varied by farm enterprises and geography [16]. Growers have reported that they can manage production risks by following prudent management practices; however, their greatest concern is the risk associated with commodity marketing [2]. As organic farming systems do not allow essential risk management tools like synthetic chemicals as in conventional farming, it may well present peculiar risks and methods of risks management [15]. Since organic farming depends upon on a whole range of management principles, such practices can help minimize risks in longer-term [15]. Reviews and meta-analyses of various crops produced in various regions around the world have shown that organic agriculture produces lower yields compared with conventional agriculture $[7,29,33]$. Since sweetpotato demand can be predicted to an extent, domestic production would mostly decide the price [2]. The global spread of organic agriculture would depend on how well it fares on the financial scale when compared to conventional farming [7, 14]. The main items that would decide the profit to be made from organic agriculture include yields, price premiums, labor, other production costs, and savings from the reduced reliance on off-farm inputs [45].

Consumers are concerned about adverse effects of excessive chemical use to humans and ecosystems and are willing to pay a premium price for food that they perceive to have no pesticide residues and to thus being safer than conventional produce [19,24]. It is important to note that before farmers begin an alternative farming system, they must believe that the economic gains would be more than the costs incurred [4]. Meenakshi et al. [23] reveal that farmers who are aware of the benefits of consuming orange-fleshed sweetpotato (OFSP) are willing to pay more for OFSP roots than their counterparts. Similarly, a study by Mwiti et al. [26] reported that the willingness to pay for quality planting materials of biofortified OFSP and the non-OFSP varieties differs by region, agro-ecological zones and varieties. Accordingly, farmers are willing to pay more for quality planting materials of non-biofortified varieties, than for the biofortified OFSP varieties and that farmers' demand for clean planting materials of non-OFSP varieties was stronger than for the OFSP varieties. Although uncertainty as to the availability of a buyer does not appear to be a major issue for sweetpotatoes, low prices at times, in combination with low yields, may cause growers to abandon a portion of 
their crop before harvesting [2]. Thus, market prices were cited as the primary source of risk in sweetpotato growing by several sources [2]. A research study comparing organic and conventional yields of crops in Austria reported conventional yield to be higher than organic and variations in yield gap exist between crop species and regions [3].

Given the importance of comparing the profitability and identify the factors responsible for variations in profit, the overall goal of this study is to analyze organic and conventional sweetpotato systems in US. The study aims at helping better understand, assess and compare yield, prices and production costs of organic and conventional sweetpotato production and their effect on net return. Findings from this study bear great potential to better understand and improve organic and conventional agricultural production systems. Furthermore, it is valuable to integrate economic aspects into holistic assessments of organic and conventional sweetpotato agricultural systems. It would help contribute to existing data and fill in the knowledge gaps on sweetpotato at the regional, national levels and worldwide. The objective of this study, therefore, is to analyze and compare the net return of organic and conventional sweetpotato production in Southeastern US and to assess the risk associated with profitability.

\section{Materials and methods}

Data source includes primary and secondary data from published studies. Secondary data utilized in this study were obtained from searching databases (google scholar), websites, journals, books and reference lists. A literature search was performed to identify the most recent studies between 2005 and 2017 highlighting the yields, market prices, variable and fixed costs of sweetpotatoes produced in organic and conventional management systems. Our literature search yielded 59 studies, however we identified 35 studies as appropriate data sources (see Additional file 1: references). These studies were examined for inclusion in our analysis based on the following criteria: (i) studies were conducted mainly in the mid-south or south-eastern regions of the United States where the sweetpotato industry is largely concentrated; (ii) studies presented the yields, prices, variable and fixed cost of sweetpotatoes produced either organically or conventionally; (iii) organic treatments were certified organic or following organic certification standards, i.e., farmers that make $<\$ 5000$ from selling organic produce and exempt from certification requirements [21]; (iv) conventional treatments, on the other hand, essentially relied on the use of chemicals such as synthetic pesticides, herbicides and fertilizers to combat weeds, pests and provide plant nourishment; (v) studies reported primary data not already included in another paper (multiple counting); (vi) the scale of the organic and conventional yield observations were comparable. The comparability of organic and conventional yields was characterized by year of planting (beyond 2005); marketable yields $(>20,000 \mathrm{lb} /$ acre and $<45,000 \mathrm{lb} / \mathrm{acre}$ ); major commercial sweetpotatoes are widely grown, common in the United States for fresh root markets and the processing industry and organic sweetpotato yield data from Tennessee State University experimental trials $[27,28]$. A 2005-2016 dataset of at least $n=5$ and $n=16$ from previous studies on organic and conventional yields, respectively was used in meta-analysis (see Additional file 2). For organic and conventional crop budgets, a dataset of $n=3$ and $n=11$ studies, respectively was utilized. Enterprise budget study, of total variable and fixed costs, from 2005 to 2016 was gathered and used in data analysis. The 2016 inflation rate was derived by first dividing the annual inflation rate of 2016 by the inflation rate in the year the study was conducted. The derived inflation value was then multiplied by the total and fixed cost prices to obtain the final 2016 southern prices used in meta-analysis. Price statistics for conventional sales prices from 2005 to 2015 and organic sales prices from 2017 were used (USDA-ERS, 2011, [39]. Thirty-five studies met these criteria representing mainly sweetpotatoes grown in the southern part of the United States, one of the 35 studies had government subsidies for organic or conventional sweetpotato.

\section{Calculation of effect sizes}

From the selected studies, we performed a meta-analysis comparing yield, price, input costs and fixed costs of organic and conventional agriculture using the following classifications: (i) sweetpotato cultivars $(n=54)$ and (ii) prices $(n=69)$ and (iii) enterprise budgets variable/ fixed costs $(n=24)$. For each data point, we calculated effect sizes comparing organic agriculture with conventional agriculture for the following: (a) yields-average yields; (b) price-average selling price that varies with the quantity of sweetpotato yield without (conventional) and with premiums (organic); (c) unit costs and net profit returns-the value of crops produced, calculated as price $\times$ yield. For studies on organic sweetpotato which did not include premiums, the average premium was listed at $34.57 \%$, calculated based on organic and conventional sweetpotato prices between 2005 and 2008 [39]. Thus, derivation of the $34.57 \%$ organic sweetpotato premium price was made based on the formula organicconventional prices)/organic prices $\times 100 \%$. Random number generation using Monte Carlo simulation from the @risk software by Palisade company was used (Palisade, N.D.). Many samples, minimum, maximum and most likely samples, where inputted and iterations made 
out of them to create some likely scenarios based on those inputs.

\section{Simulation model}

Given the different systems of sweetpotato production, evaluation of profitability is important for producers to identify the most appropriate choice that provides the highest income. Therefore, risk analysis is mainly focused on the producer's point of view concerning sweetpotato production under organic and conventional systems. In sweetpotato, the cost of production includes commonly used cost categories from land preparation to harvesting, thus various uncertainty variables need to be identified and considered for a possible range of net return from sweetpotato production. Monte Carlo simulation is a mathematical method that primarily measures risk through data analysis before a decision is made. It functions by randomly generating risk profiles or possible outcomes values of factors with uncertainty, calculates profit and the probability of obtaining the expected profit. The profit function can be represented by:

$$
\pi_{j}=\Sigma\left[\left(P_{j} * Y_{j}\right)-\left(Q_{j} * P_{I j}\right)-F C_{j}\right],
$$

where $\pi_{j}$ represents the profit of $j$ th farm $(\$ / \mathrm{ha}), Y_{j}$ represents a yield of sweetpotato in $j$ th farm $(\mathrm{kg} / \mathrm{ha})$ which is stochastic, $P_{j}$ represents selling price of sweetpotato $(\$ /$ $\mathrm{kg}$ ) in $j$ th farm which is stochastic, $Q_{i j}$ represents $i$ th variable input for sweetpotato in $j$ th farm, $P_{I j}$ is the price of input $i$ and $\mathrm{FC}_{j}$ represents total fixed cost for $j$ th farm.

\section{Results and discussion}

\section{Distribution of input costs, yield and price}

During the Monte Carlo simulation, a large number of random iterations are created based on the input data provided and the range of net returns with different distributions is simulated. We used pert distribution to create a probability distribution for price, yield and input costs (Fig. 1). The Pert distribution is a smooth version of the uniform distribution or triangular distribution and it helps us get a better estimate. For the pert distribution, the more the surface area of the curve, the more likely the samples would come from that area and vice versa. There is a bias toward the middle of the distribution where the peak houses the most likely to occur values. The height of the curve shows the probability or likelihood that the measured value would happen, and the $x$-axis shows the range. Below $100 \%$ of the blue area represents $100 \%$ of our samples on the graph ranging between the minimum selling price of sweetpotato at $\$ 0.08$ and the maximum selling price at $\$ 0.09 / \mathrm{kg}$. The pert distribution on the unit cost price of conventionally produced sweetpotato vaguely shows that there is a $5 \%$ chance it would be $\$ 0.04$ or less and a $5 \%$ chance the sweetpotatoes would be $\$ 0.09 / \mathrm{kg}$ or greater. On the issue of yield in conventional production, there is a $90 \%$ probability of having the sweetpotato yield in the range of $25,982-35,846 \mathrm{~kg} / \mathrm{ha}^{-1}$.

On the other hand, the pert distribution on the selling price of organically produced sweetpotato shows there is a $5 \%$ chance that sweetpotatoes would sell for more than $\$ 0.13 / \mathrm{kg}$ and a $95 \%$ chance, it would sell for less than that. The production cost distribution, of organically produced sweetpotato, showed (at the 90th percentile) that, the production costs varied between $\$ 0.03$ and $\$ 0.05 / \mathrm{kg}$ of sweetpotato. A $90 \%$ probability value is possible of organic sweetpotato yields falling within $24,850-35,014 \mathrm{~kg} / \mathrm{ha}^{-1}$.

According to our estimated results, the minimum selling price of sweetpotato was $\$ 0.08$ and the maximum was $\$ 0.13 / \mathrm{kg}$ (Figs. 1, 2). Our results showed that the highest selling price of sweetpotato was noted in the organic systems. It is important to note, however, that in the pert distribution (as a better triangular distribution) it is hard to identify the weighting of prices. In this study, minimum and the maximum cost of production was higher in the conventional inferring such method of sweetpotato production could be potentially riskier. The findings

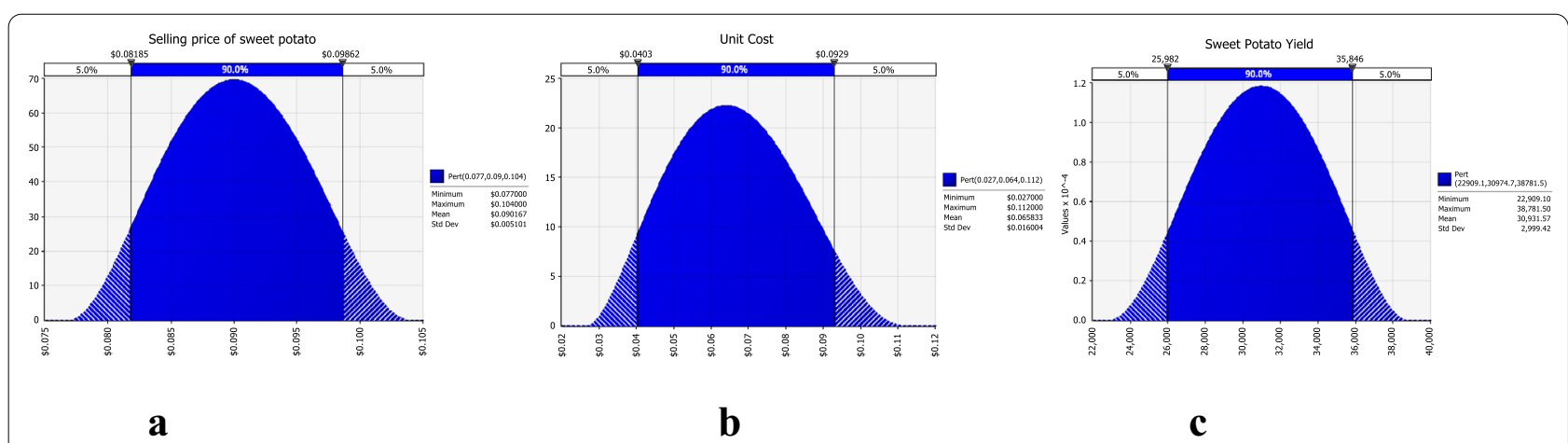

Fig. 1 Distribution of a selling price, $\mathbf{b}$ unit cost, $\mathbf{c}$ yield of sweetpotato under conventional production 


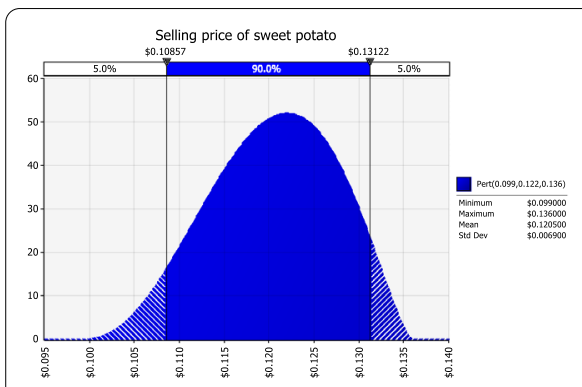

a

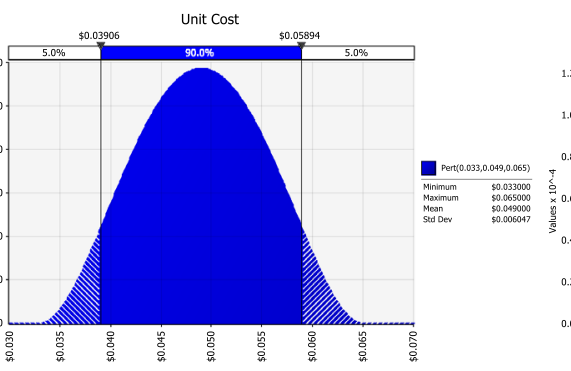

b

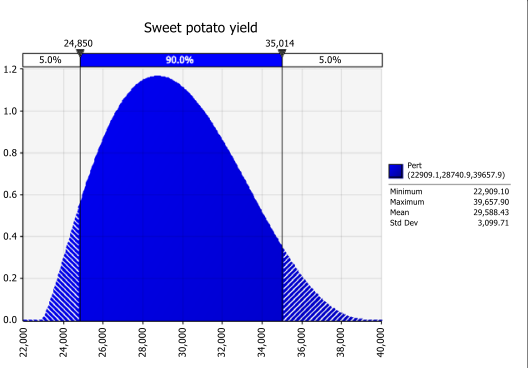

C

Fig. 2 Distribution of a selling price, $\mathbf{b}$ unit cost, $\mathbf{c}$ yield of sweetpotato under organic production

from this research revealed that lower sweetpotato yields are to be expected in the organic sweetpotato production systems compared with the conventional within the $90 \%$ percentile. However, the overall maximum yield of sweetpotatoes was higher in the organic system than in conventional (Fig. 2). A previous meta-analysis study of available data, on global yield performance by researchers, had reported overall, that organic yields are typically lower than conventional yields. Scientists have determined that these variations in yield depend on the production method, crop cultivated, soil properties and climatic conditions [34].

De Ponti et al. [7] compiled and analyzed a meta-data set 25 of 362 published organic-conventional comparative crop yields and discovered yield gaps and that organic agriculture differed between crops and between regions. However, it was difficult to provide explanations for the differences. De Ponti et al. [7] concluded that to some extent, there was an increase in the yield gap between organic and conventional agriculture as conventional yields increased.

\section{Probability distribution and fit comparison}

This distribution helps us calculate the measure of uncertainty or certainty associated with our net profit in sweetpotato production. In conventional sweetpotato production, range of net returns (Fig. 3) shows that there is a $5 \%$ probability of having either a net profit of - $\$ 315 / \mathrm{ha}^{-1} /$ year and a $95 \%$ chance of gaining a net profit of $\$ 1,467 /$ ha year $^{-1}$. The fit comparison shows a profit follows beta general distribution with a baseline mean net profit value of $\$ 581.93 /$ ha year $^{-1}$ for the conventionally produced sweetpotato. The histogram charts (Fig. 3) show different percentage values on the horizontal axis above the chart. On the horizontal axis below the chart, the range of our minimum values $(\$-1188)$ and maximum or best case scenario (\$2513) net profit values for conventional sweetpotato has been shown and also on the legend on right side of the histogram. This results may be of a concern because a negative net profit value could be generated. In the upper 95th percentile, there is only a $5 \%$ chance that a net profit of over $\$ 1467$ would be generated per hectare and the reverse is the case with a $5 \%$ chance of $-\$ 315$ produced in the lower $95 \%$ percentile.

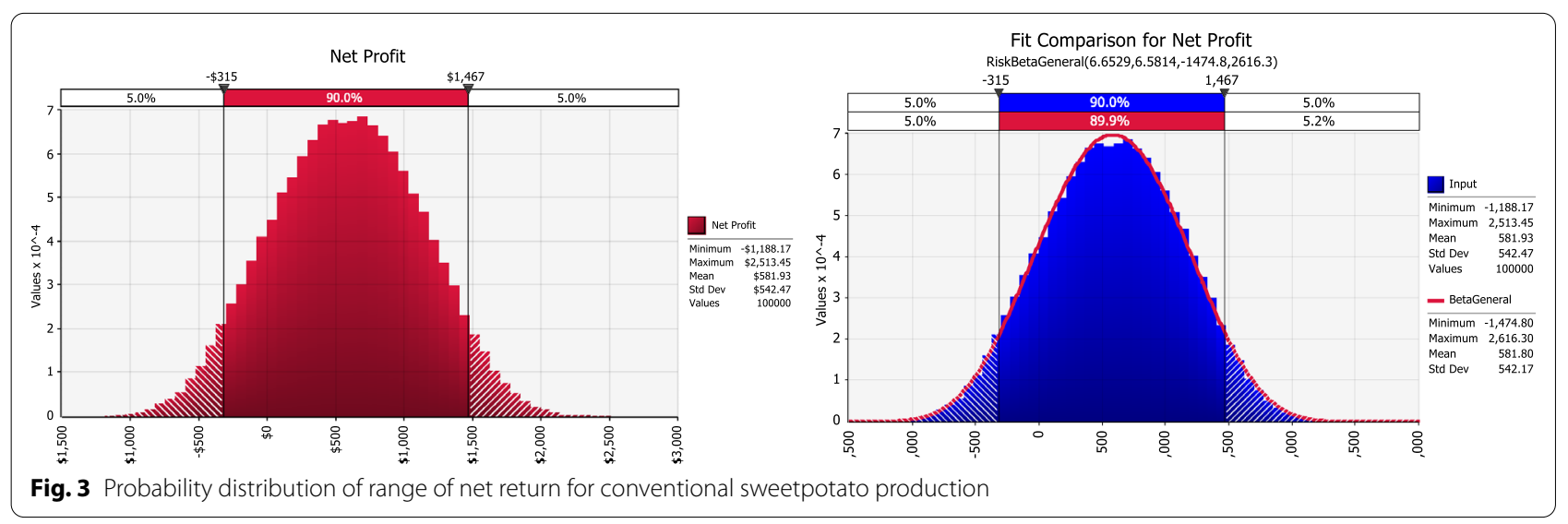


The probability distribution of net return of organic sweetpotato (Fig. 4) at $90 \%$ confidence interval reveals that the range of net return could vary from the minimum gain of $\$ 1250$ to a maximum of $\$ 2500$. The baseline means net profit value of sweetpotato produced in the organic system was estimated to be $\$ 1866.93 / \mathrm{ha} \mathrm{year}^{-1}$.

\section{Sensitivity analysis}

The spider graph shows on the horizontal axis (Fig. 5) percentile of the input and the value of the net profit output on the vertical axis that an increase in unit cost leads to decreased profit and vice versa as evidenced by the red line going in the opposite direction (see scatter plot chart to see the detailed relationship between the unit cost input and net profit output) within conventional production systems. The higher selling price and yield show an increasing trend for net profit. There is very little relationship between the sweetpotato selling price and yield and the net profit. The blue line indicating selling price is not nearly as steep as the red for unit cost. It illustrates that the higher the selling price, the higher the net profit value and vice versa. The near flatness of the green line indicating sweetpotato yield illustrates that it is not an important factor influencing the net profit in sweetpotato production and there is an extremely little relationship on sweetpotato yield and whether we make a profit or loss. Overall, the net profit return is higher with decreased unit cost in organic. As sweetpotato yield (green line) and selling price (blue line), respectively, increase, there is a decrease in net profit, thus both have a stronger influence on net profit in organic sweetpotato production than in the conventional (Fig. 6).

The tornado graphs illustrating net profit, further provide evidence on the sensitivity of comparison of risk factors on profitability and builds relationships between inputs. In organic production systems, sweetpotato yield has more effect on net return than price. A negative correlation relationship was observed between the selling price and the number of units sold. Increasing selling prices and sweetpotato yields have positive correlation while unit costs have decreased relationship in the conventional sweetpotato production system. The same trend is observed in the organic systems where sweetpotato yield and prices have positive effect on net return while unit costs shows negative effect on profitability.

Because sweetpotatoes are a traditional part of the holiday meal, many consumers are reluctant to forego their purchase of sweetpotatoes even when supplies
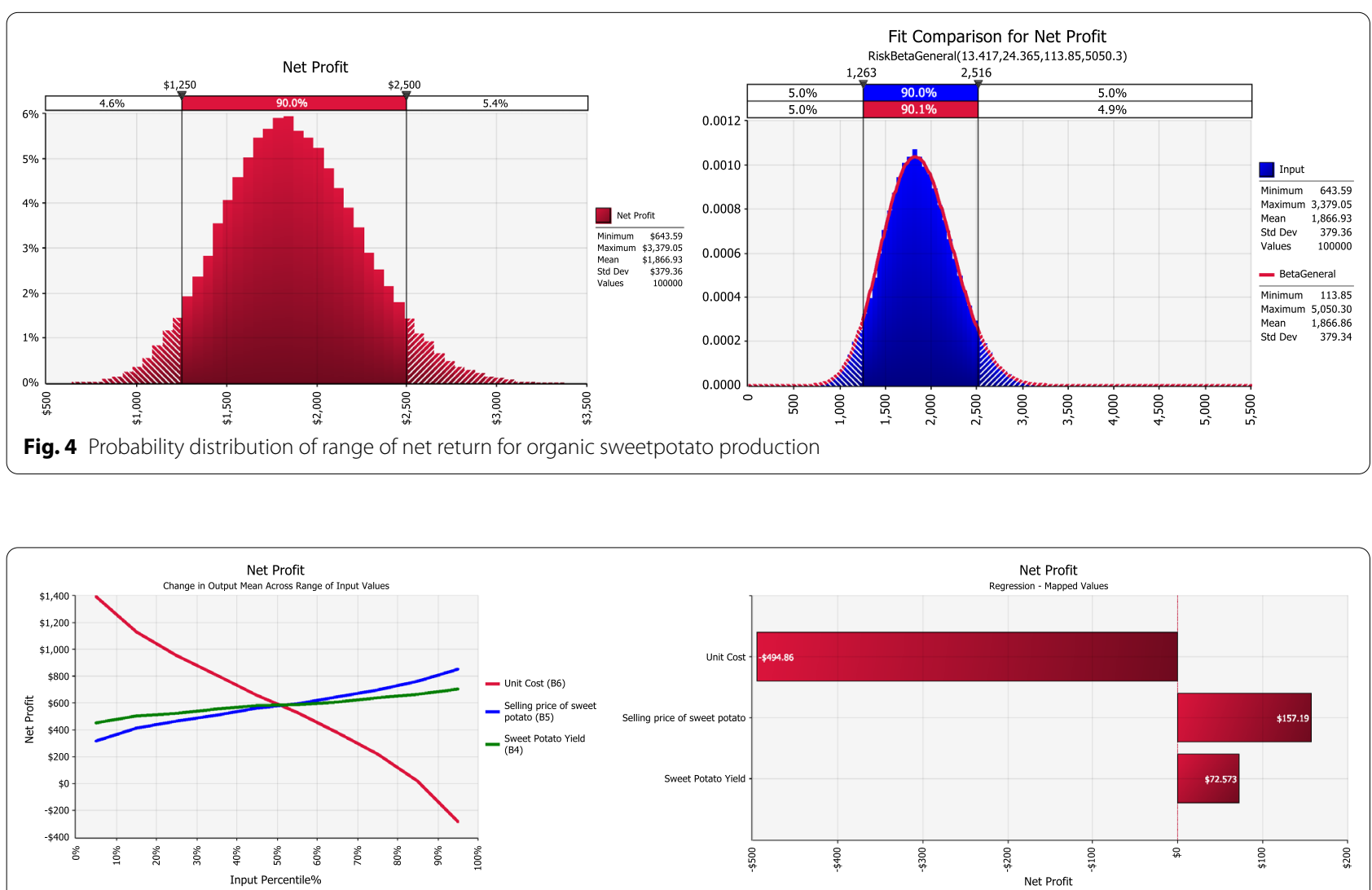

Fig. 5 Sensitivity of risk factors on net return of conventional sweetpotato production 


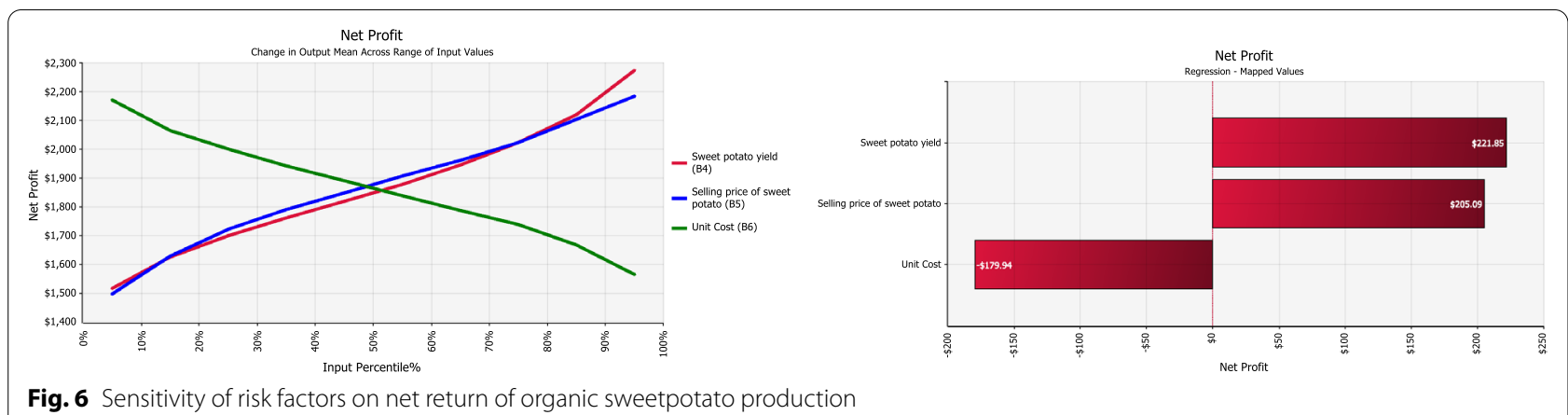

are short and prices relatively high [2]. Consequently, small changes in the number of sweetpotatoes result in relatively large changes in price [2]. Large year-to-year changes in prices are associated with relatively small changes in the available supply and this type of price and quantity relationship is referred to as an inelastic demand [2]. One widely quoted study of the demand for food commodities in the United States estimates that each $0.5 \%$ rise (decline) in the quantity of fresh sweetpotatoes demanded is associated with a $1 \%$ decline (increase) in the farm price [12].

Time and energy should be focused on decreasing the cost of sweetpotato production in conventional sweetpotato production systems as this has the most impact on our net profit output. While North Carolina, have posted the largest production gains, all producers have benefited from the price-bolstering effects of rising export volumes and domestic demand for sweetpotatoes [18]. Indeed, sweetpotato prices have increased by more than $50 \%$ between 2000 and 2014 to attain a new record high for the 2013/14 marketing year [18]. Further, per capita consumption and trade trends indicate that demand for sweetpotatoes will be sustained into the near future. Dobbs et al. [10] indicated that "price premiums associated with organic niche markets and 'family farms' are at risk when large-scale organic producers or processors enter the market if demand does not expand sufficiently". Conversely, organic farming practices, especially crop rotation, can be used to lower risk over a very long period [15]. Hansen et al. [15] discovered, however, that crop rotation as cultural practice in organic farming, provided higher annual profit on average than crop rotation methods applied in conventional farming, only when a premium price was placed on the organic product. For several years, the price premium ranged between 100 and $250 \%$ of conventional vegetables [4]. In recent years, however, the price premium has declined slightly [13]. Organic agriculture and research which only started to garner attention in the 1970 s, close to 50 years after the introduction of conventional agriculture, involves a wide range of systematic production practices, that are a lot more challenging to establish and would require more time to develop profitably [4]. Brumfield et al. [4] used budgeting methods to analyze the costs and benefits of adopting integrated crop management (ICM) or organic methods versus conventional agriculture for tomatoes (Lycopersicon esculentum Mill.), sweet corn (Zea mays L. var. saccharata), and pumpkins (Cucurbita pepo L.). In their study, organic systems for tomatoes, corn, and pumpkins were shown to require more labor and have lower marketable yields than conventional or ICM systems. The organic systems also had the lowest net returns however because of the organic price premium, the net returns were fairly close to those for conventional and ICM systems.

As organic vegetable production becomes a goal for many, premium pricing might drop and organic growers would need to develop alternative means to reduce costs and expand yields [4]. The net profit results from our study support the school of thought that in some circumstances, with proper management practices, certain crops and some growing conditions organic systems can thus nearly match and surpass conventional yields. For organic agriculture to be used effectively as a means of producing food sustainably we must first fully grasp the reason why organic yields are lower as we concurrently examine the many socio-economic and environmental gains of organic crop production systems. [34]. A major question posed by members of developing nations is whether organic agriculture can support an increase in income among smallholder farmers while improving global and household food security [34].

It has been suggested that organic agriculture may improve farmer livelihoods owing to cheaper inputs, higher and more stable prices, and risk diversification [33]. However, it is pertinent to remember that, organic agriculture in developing countries and many parts of the world is often an export-oriented system tied to a certification process by international bodies, and its profitability can vary between locations and years. 


\section{Conclusions and recommendations}

In this study, the economic risks or variability in net income of organic and conventional sweetpotato production methods as influenced by yields, selling price and unit cost of production was evaluated. The results based on primary and secondary data analysis revealed that, the unit cost of production was observed to be $17 \%$ higher in the conventional sweetpotato production, inferring such method of producing sweetpotatoes could be potentially riskier. Despite it is high production cost, farmers are encouraged to go into sweetpotato production as it appears to be profitable. Additionally, 2\% lower sweetpotato yields and 14\% higher selling prices are to be expected in the organic sweetpotato production systems when compared with the conventional. Furthermore, when compared to the conventional, profitability could be up to $52 \%$ higher in organic production systems. Our findings suggest that organic sweetpotato production is profitable even with slightly lower yields than the conventional. The results of this study which consists of the determination of the economic feasibility of organic and conventional sweetpotato production, can be applied in the financial analyses of tuber/root production in both developing and developed countries.

Generally, farming is a risky business. Production risks may be minimized by following prudent management practices and farmers may continue to reevaluate labor requirements from day to day to determine if there are changes that can be made to become more labor efficient. If the same yield can be maintained with less labor, costs per unit should decrease. In addition, more research should be done on consumer-based pricing to see how consumers' value sweetpotato produced using both systems. A clearer picture of consumer attitudes and willingness to pay may help both industries in the future. Further studies should be conducted on conventional treatments without synthetic pesticides and fertilizers as these systems perhaps, may display lower external input costs that might make them more profitable and similar to organic systems.

While this study makes every effort to model a production system based on typical, real-world practices, it cannot fully represent financial, agronomic and market risks, which affect the profitability and economic viability. There are many factors to consider in balancing the benefits of organic and conventional agriculture, and there are no simple ways to determine a clear 'winner' for all possible farming situations. However, instead of continuing the ideologically charged 'organic versus conventional' debate, we should systematically evaluate the costs and benefits of different management options.

\section{Supplementary Information}

The online version contains supplementary material available at https://doi. org/10.1186/s40066-021-00298-6.

Additional file 1: Authors of the studies used in Meta-Analysis.

Additional file 2 Data sources used in the study.

Acknowledgements

Not applicable.

Authors' contributions

SN collected data, analyzed and interpreted the results of economic analysis. PI performed Monte Carlo simulation. DN supervised and guided collecting field data from organic production systems. ITA and ON performed review of literature and collected secondary data. All authors read and approved the final manuscript.

\section{Funding}

This research is funded by the US Department of Agriculture (USDA) Evans Allen program.

Availability of data and materials

The datasets collected and analyzed during the current study are available from the corresponding author on reasonable request. All data generated or analyzed during this study are included in this published article [and its supplementary information files].

\section{Declarations}

Ethics approval and consent to participate

Not applicable.

Consent for publication

Not applicable.

Competing interests

The authors declare that they have no competing interests.

Author details

${ }^{1}$ Department of Agricultural and Environmental Sciences, Tennessee State University, 3500 John A. Merritt Blvd, Nashville, TN 37209, USA. ${ }^{2}$ Marketing Unit, Department of Business Administration, Faculty of Management Sciences, University of Lagos, Lagos, Nigeria.

Received: 24 September 2020 Accepted: 31 March 2021

Published online: 17 August 2021

References

1. Apanovich N, Mazur RE. Determinants of seasonal food security among smallholder farmers in south-central Uganda. Agric Food Secur. 2018:7:87.

2. Bertelson D, Robert D, Joy H, Fred H, Hyunok L, John L, Gary L, Agapi S, Glenn Z. Sweet potatoes: an economic assessment of the feasibility of providing multiple-peril crop insurance. Economic Research Service, USDA. http://www.rma.usda.gov/pilots/feasible/pdf/sweetpot.pdf. 1994:44.

3. Brückler M, Resl T, Reindl A. Comparison of organic and conventional crop yields in Austria. Die Bodenkultur J Land Manage Food Environ. 2018;68(4):223-36.

4. Brumfield RG, Rimal A, Reiners S. Comparative cost analyses of conventional, integrated crop management, and organic methods. HortTechnol. 2000;10(4):785-93.

5. Chase C. Using enterprise budgets to make decisions. lowa State University Extension, Ames. 2006. p. 1-7. http://www.extension.iastate.edu/ AgDM/crops/pdf/a1-19.pdf. 
6. Crowder DW, Reganold JP. Financial competitiveness of organic agriculture on a global scale. Proc Natl Acad Sci. 2015;112(24):7611-6.

7. De Ponti T, Rijk B, Van Ittersum MK. The crop yield gap between organic and conventional agriculture. Agric Sys. 2012;108:1-9.

8. De Schutter O. Report submitted by the special Rapporteur on the right to food. United Nations. 2010. p. 21.http://www2.ohchr.org/english/ issues/food/docs/A-HRC-16-49.pdf.

9. Debebe S, Zekarias EH. Analysis of poverty, income inequality and their effects on food insecurity in southern Ethiopia. Agric Food Secur. 2020;9:16.

10. Dobbs TL, Shane RC, Feuz DM. Lessons learned from the Upper Midwest organic marketing project. Am J Alt Agric. 2000;15(3):119-28.

11. Ezin V, Quenum F, Bodjrenou RH, et al. Assessment of production and marketing constraints and value chain of sweet potato in the municipalities of Dangbo and Bonou. Agric Food Secur. 2018;7:15.

12. George PS, King GA. Consumer demand for food commodities in the United States with projections for 1980. California Agric Exp Station. 1971;26:166.

13. Glaser LK, Thompson GD. Demand for organic and conventional frozen vegetables. Selected paper presented at the American Agricultural Economics Association. In: Annual Meeting, Nashville, Tennessee; 1999. p. 8-11.

14. Halberg N, Sulser TB, Høgh-Jensen H, Rosegrant MW, Knudsen MT. Global development of organic agriculture: challenges and prospects. In: Halberg N, Alrøe HF, Knudsen MT, Kristensen ES, editors. CABI. UK Wallingford; 2007. p. 277-322.

15. Hanson J, Dismukes R, Chambers W, Greene C, Kre A, men. Risk and risk management in organic agriculture: views of organic farmers. Renew Agrc Food Syst. 2004;19(04):218-27.

16. Harwood JL, Heifner R, Coble K, Perry J, Somwaru A. Managing risk in farming: concepts, research, and analysis. Managing risk in farming: concepts, research, and analysis. USDA, ERS Agric Econ Report. 1999. pp. 130.

17. Islam S, Porter OA, Izekor SE, Garner JO. Quality characteristics and yield attributes of sweetpotato (Ipomoea batatas L.) genotypes grown under sustainable cultural conditions. J Food Agric Environ. 2007;5(3/4):220.

18. Johnson T, Wilson N, Michelle RW, Deacue F, Jennifer KB. Vegetables and pulses outlook: special article commodity highlight: sweetpotato. USDA Economic Research Service. 2015; VGS-355-SA1. http://www.ers.usda. gov/media/1834605/vgs-355-sa1.pdf.

19. Jolly DA. Differences between buyers and nonbuyers of organic produce and willingness to pay organic price premiums. J Agribus. 1991;9:97-111.

20. Kays SJ. Flavor-the key to sweetpotato consumption. In: II International Symposium on Sweetpotato and Cassava: Innovative Technologies for Commercialization. Intl Soc Hort Sci Acta Hort. 2005;703: 97-106.

21. Klonsky K. A look at California's organic agriculture production. Agric Resour Econ Update. 2010;14(2):8-11.

22. Mclntyre BD, Herren HR, Wakhungu J, Watson RT. Agriculture at a crossroads: international assessment of agricultural knowledge. Science and Technology Development (IAASTD): Global report. 2009; pp. 606. http:// www.agassessment.org/.

23. Meenakshi JV, Banerji A, Manyong V, Tomlins K, Hamukwala P, Zulu R, Mungoma C. Consumer acceptance of provitamin A orange maize in rural Zambia (HarvestPlus Working Paper No. 4). 2010; pp. 43.

24. Misra SK, Huang CL, Ott SL. Georgia consumers' preference for organically grown fresh produce. J Agribus. 1991;9:53-63.

25. Mota AA, Lachore ST, Handiso YH. Assessment of food insecurity and its determinants in the rural households in Damot Gale Woreda, Wolaita zone, southern Ethiopia. Agric Food Secur. 2019;8:11.

26. Mwiti FK, Okello JJ, Munei K, Low J. Assessment of farmer willingness to pay for quality planting materials of biofortified and non-biofortified varieties of sweetpotato. 2016. In: 2016 Afr Assoc of Agri Econ (AAAE) Fifth Intl Conf Addis Ababa; Ethiopia (No. 249327).

27. Nwosisi S, Nandwani D, Pokharel B. Yield performance of organic sweetpotato varieties in various mulches. Horticulturae. 2017;3(3):48.

28. Nwosisi S, Nandwani D, Hui D. Mulch treatment effect on weed biomass and yields of organic sweetpotato cultivars. Agronomy. 2019;9(4):190.

29. Palisade ND. Palisade knowledge base. Risk simulation and graphical results. 2016;7. https://kb.palisade.com/index.php?pg=kb.chapter\&id= 53.

30. Ponisio LC, M'Gonigle LK, Mace KC, Palomino J, De Valpine P, Kremen C. Diversification practices reduce organic to conventional yield gap. Proc $R$ Soc B Biol Sci. 2015;282(1799):20141396.

31. Qaim M. The economic effects of genetically modified orphan commodities: projections for sweetpotato in Kenya. Ithaca, NY: ISAAA; 1999;13:47 https://www.isaaa.org/kc/Publications/pdfs/isaaabriefs/Briefs\%2013.pdf.

32. Reganold JP, Wachter JM. Organic agriculture in the twenty-first century. Nat Plants. 2016;2(2):1-8.

33. Scialabba N, Hattam C, editors. Organic agriculture, environment, and food security. Food and Agric Org of United Nations Rome. 2002;4:258

34. Seufert V, Ramankutty N, Foley JA. Comparing the yields of organic and conventional agriculture. Nature. 2012;485(7397):229-32.

35. Silvestri S, Sabine D, Patti K, et al. Households and food security: lessons from food secure households in East Africa. Agric Food Secur. 2015;4:23.

36. Simonne A, Ozores-Hampton M, Treadwell D, House L. Organic and conventional produce in the US: examining safety and quality, economic values, and consumer attitudes. Horticulturae. 2016;2(2):5.

37. Stark JC, Thornton M, Nolte P, editors. Potato production systems. Berlin: Springer Nature; 2020.

38. Trewavas A. Urban myths of organic farming. Nature. 2001:410(6827):409-10.

39. USDA-AMS. Report results-Sweetpotato. Specialty crops market news. 2017.

40. USDA-NASS. 2012. Census of agriculture highlights. Organic farming results from the 2014 Organic survey. 2015;ACH12-29:4. http://www. agcensus.usda.gov/Publications/2012/Online_Resources/Highlights/ Organics/2014_Organic_Survey_Highlights.pdf.

41. USDA-NASS. Crop Production. Sweetpotato Area Planted and Harvested, Yield, and Production - States and United States: 2013 and 2014. 2015; ISSN 1936-3737:33. http://www.usda.gov/nass/PUBS/TODAYRPT/crop0 615.pdf.

42. USDA-NASS. Certified organic survey, 2015 summary. Certified Organic Vegetables, Potatoes, and Melons Grown in the Open Harvested. 2016; pp. 29. http://usda.mannlib.cornell.edu/usda/current/OrganicProduction/ OrganicProduction-09-15-2016.pdf.

43. USDA-NASS. North American potatoes: Combined United States potato and Canadian potato production up 2 percent from 2018.2020. https:// www.nass.usda.gov/Publications/Todays_Reports/reports/uscp0220.pdf. Accessed 17 Jun 2020.

44. Wakie TT, Neven LG, Yee WL, Lu Z. The establishment risk of Lycorma delicatula (Hemiptera: Fulgoridae) in the United States and globally. J Econ Entomol. 2020;113(1):306-14.

45. Zentner RP, Basnyat P, Brandt SA, Thomas AG, Ulrich D, Campbell CA, Nagy CN, Frick B, Lemke R, Malhi SS, Olfert OO. Effects of input management and crop diversity on economic returns and riskiness of cropping systems in the semi-arid Canadian Prairie. Renewable Agric Food Syst. 2011;26(3):208-23.

\section{Publisher's Note}

Springer Nature remains neutral with regard to jurisdictional claims in published maps and institutional affiliations. 